\title{
A quantitative sampler for collecting invertebrates associated with deep submerged vegetation
}

\author{
Ryszard Kornijów
}

Received: 25 June 2014/ Accepted: 9 September 2014/Published online: 18 September 2014

(C) The Author(s) 2014. This article is published with open access at Springerlink.com

\begin{abstract}
Only few of the numerous samplers for collecting invertebrate fauna associated with vegetation permit sampling at depths of more than approximately $0.5 \mathrm{~m}$. This paper describes a sampler allowing collection of epifauna from submerged plants at a depth of up to approximately $2 \mathrm{~m}$, growing in varied densities. The sampler is composed of two panels made of duralumin, connected on one side by means of piano-hinges. One of the panels has an opening covered with mesh, and the other is equipped with a cone-shaped net and detachable sample concentrator at its end. The sampler is coupled with a manipulator with a several meter extension for lowering the sampler under water, as well as for its opening, and closing. The initial assessment of the sampler efficiency, verified in beds of Potamogeton perfoliatus, provided similar results as two other, older and commonly used samplers. In comparison with the older devices, the sampler has the advantage of permitting collecting samples from greater depths. It also enables studying both the vertical and horizontal distribution of invertebrates within a plant patch.
\end{abstract}

Handling Editor: Piet Spaak.

R. Kornijów $(\square)$

Department of Fisheries Oceanography and Marine Ecology, National Marine Fisheries Research Institute, Kołłątaja 1, 81-332 Gdynia, Poland

e-mail: ryszard.kornijow@mir.gdynia.pl
Keywords Sampling methods - Epiphytic fauna . Macrophytes

\section{Introduction}

Macrophytes together with the epiphytic assemblages inhabiting their surface, such as bacteria, fungi, algae, and protozoa, as well as invertebrates grazing on such organisms (epifauna), constitute a specific biocoenosis in the littoral of various aquatic, both freshwater and saline ecosystems. Due to its frequent mass occurrence, epiphytic fauna can be of considerable importance as a consumer of phytoperiphyton and therefore a "cleaner" of the surface of plants (e.g., Kairesalo et al. 1987; Brönmark 1994; Jones et al. 2002; James et al. 2000). In certain situations it can also cause a substantial loss of plant biomass (Newman 1991; Kornijów 1996; Gross and Kornijów 2002). Epiphytic fauna is readily eaten by many fish species (Jones et al. 1998; James et al. 2000; Jones and Waldron 2003; Kornijów et al. 2005). This may lead to a cascading effect and enhanced growth of macrophytes (Brönmark 1994). The predation pressure of fish on epiphytic fauna depends, among others, on the plant density and the resources of alternative food, e.g., zoobenthos and planktonic crustaceans (e.g., Diehl and Kornijów 1998; Perrow et al. 1999; Kornijów et al. 2005). High importance of epifauna as food supply for waterfowl is also well known (Matuszak et al. 2014). 
Research on such relationships requires the application of relevant sampling techniques. Whereas collecting quantitative samples of phytoperiphyton poses no significant methodological problems, sampling epiphytic fauna constitutes a serious challenge for limnologists (Moss 2010). Sampling fauna associated with vegetation involves the application of various types of equipment, from very simple (Kangas 1972; Kornijów 1998; Colon-Gaud and Kelso 2003) to very complex ones (e.g., Gillespie and Brown 1966; McCauley 1975; Galanti 1995). The high number and variety of technological solutions probably results not only from the inventiveness of the authors, but also from the vast variety of the morphological structure of plants sampled for analyses. Notice, for example, the differences between the delicate thalli of filamentous algae and the hard stems of reed. Moreover, vegetation coverage may vary from very dense carpets to dispersed single patches or stems. The selection of the sampler should also consider the specificity of the groups of animals subject to the study, including those firmly or rather loosely attached to plant surfaces, as well as those swimming among the vegetation.

Two types of epiphytic fauna samplers are generally distinguished:

1. for emergent plants (Gerking 1957; McCauley 1975; Amoros 1980; Kornijów and Kairesalo 1994),

2. for submerged vegetation, floating-leaved plants, and algal mats (e.g., Macan 1949; Gerking 1957; Korinkova 1971; Kangas 1972; McCauley 1975; Martin and Shireman 1976; Minto 1977; Downing 1986; Czernik and Rybak 1995; Kornijów 1998; Marklund 2000; Colon-Gaud and Kelso 2003).

The variety of methods encourages researchers to undertake studies aimed at the comparison of various samplers (e.g., Macan 1977; Cheal et al. 1993; GarciaCriado and Trigal 2005; Sychra and Adámek 2010).

In spite of the availability of a high number of different samplers, only some of them permit sampling epiphytic fauna from depths higher than $1 \mathrm{~m}$ (literature review in Downing 1984). Because of the above, it is frequently necessary to collect samples by SCUBA diving or snorkeling (e.g., Kangas 1972; Gross and Kornijów 2002), which is not always possible for various reasons.

This paper presents the construction of a quantitative sampler for collecting epifauna associated with

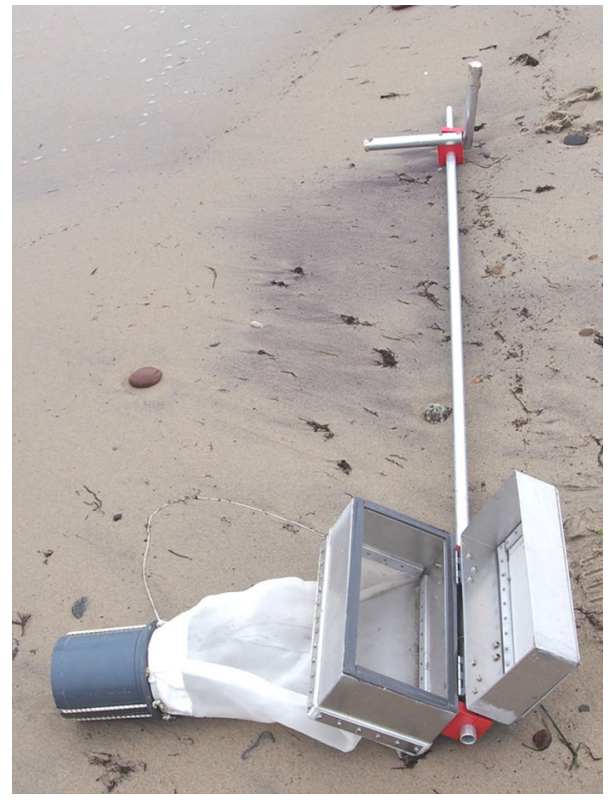

Fig. 1 General view of the sampler in the open position

submerged plants growing at a depth to about $2 \mathrm{~m}$, and in various covers.

\section{Technical description}

The main sampling part of the sampler resembles apparatuses by other authors (Downing 1986; Kornijów 1998; Colon-Gaud and Kelso 2003). It is composed of two panels, made of duralumin, connected on one side by means of piano-hinges, and a manipulator with 1-2 $\mathrm{m}$ extension used for lowering the sampler under water, opening, and closing it (Fig. 1).

The panels have dimensions of $30 \mathrm{~cm} \times 20 \mathrm{~cm} \times$ $16 \mathrm{~cm}$ (height $\times$ width $\times$ depth). One panel has an opening covered with mesh, and weather stripping along its external edge. The other panel is coupled with a cone-shaped net with a length of $30 \mathrm{~cm}$. The purpose of the net is to reduce back pressure while closing the sampler. A similar solution preventing the occurrence of a shock wave is applied in some other samplers (Czernik and Rybak 1995; Marklund 2000).

A ring $(3 \mathrm{~cm}$ long, $10 \mathrm{~cm}$ in diameter) with a detachable sample concentrator $(10 \mathrm{~cm}$ long, $10 \mathrm{~cm}$ in diameter), both made of PVC, is mounted at the end of the net (Figs. 2, 3). Mesh identical as that used for making the net is glued to the lower part of the sample 


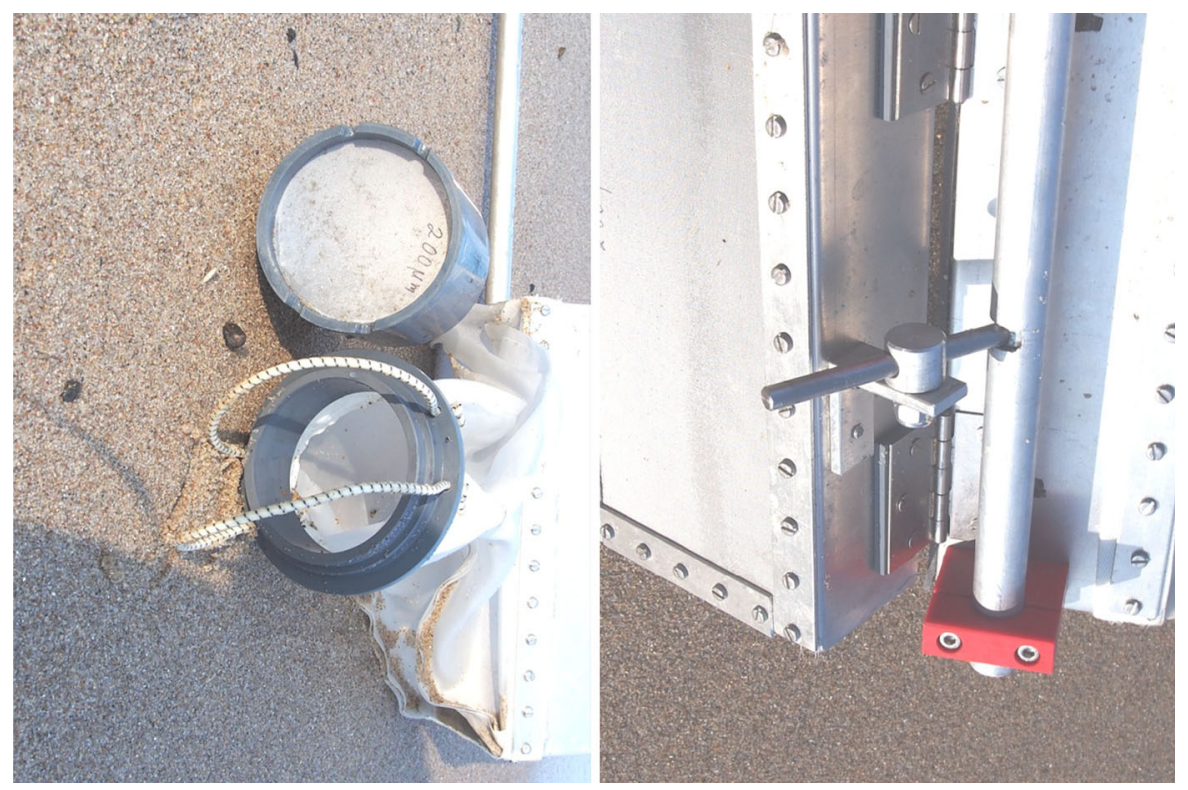

Fig. 2 Detachable sample concentrator with the sieve (left) and the lower part of the manipulator with the spindle for closing the sampler (right)

concentrator, functioning as a sieve. The concentrator is attached to the ring by means of rubber expanders.

The sampler is opened and closed by means of the manipulator-a system of two tubes made of aluminum, one inserted inside the other. At the top end, they are equipped with handles facilitating manipulation. At the bottom end, they are connected to the panels, whereas the external tube is permanently connected to the panel with the cone-shaped net, and the internal tube pulls or pushes the other panel by means of a spindle therefore opening or closing the sampler (Figs. 2, 3). The closing mechanism is very effective and permits closing the sampler even onto stiff vegetation.

The length of the manipulator depends on the sampling depth. At depths of more than $2 \mathrm{~m}$, the application of the sampler becomes more difficult.

The mesh used in the cover of the panel opening, the cone-shaped net and the sample concentrator should have the same size depending on the size of collected invertebrates and the study objective. In the sampler presented here, the mesh size amounted to $200 \mu \mathrm{m}$. It seems to be a good compromise, permitting minimizing the risk of escape by small invertebrates, and simultaneously ensuring easy filtration of water.

\section{Operation of the sampler}

Sampling should be performed from a boat. It involves slow lowering of the closed sampler to the plants while holding the manipulator. Immersing the sampler in the closed position permits the avoidance of sieving and trapping of dislodged or actively swimming invertebrates, such as water mites, bugs, and beetles, and their overrepresentation in the sample. Only when the sampler reaches the plants, it is opened by means of the handles and placed so that the plants are between the panels. The sampler is then closed and retrieved to the boat together with the plants and fauna. Water leaks out from the sampler through the mesh. Any stems of plants protruding outside of the sampler are trimmed manually with scissors.

Next, the sample of aquatic vegetation together with fauna is transferred into the sample concentrator by rinsing the net with water from outside. When no more debris on the net is visible, the sample concentrator can be detached from the ring, and the sampled material can be transferred to plastic containers or zip bags, and kept in a cooler.

I recommend keeping samples in containers without water, but with air volume at least the same as the 


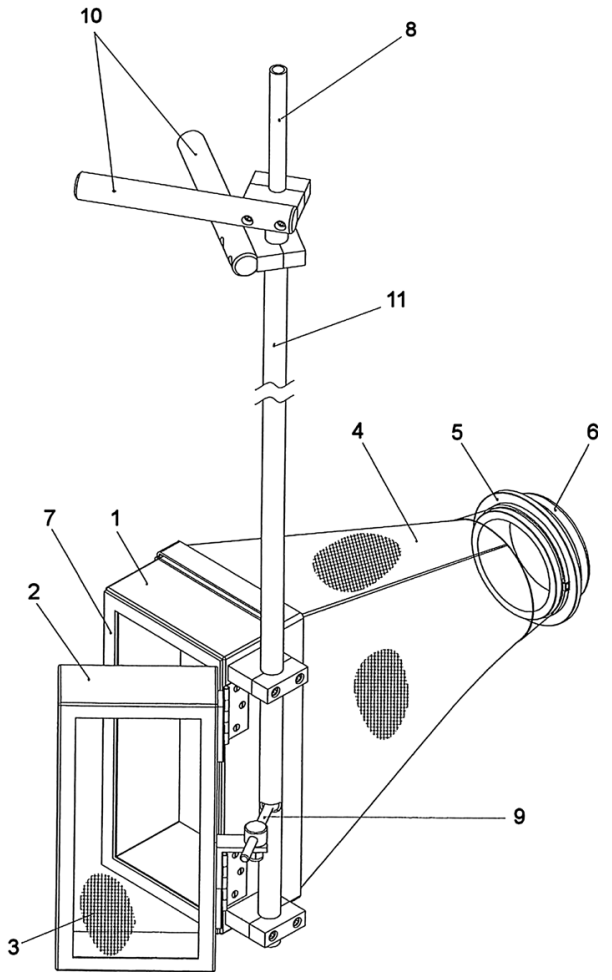

Fig. 3 Details of the construction of the sampler. The panel (2) with an opening covered with mesh (3), closed or opened by means of the spindle (9) connected with the internal tube $(8)$ of the manipulator. The other panel permanently connected to the external tube (11) of the manipulator (1) with weather stripping (7) and the cone-shaped net (4) with the ring (5) and detachable sample concentrator at its end $(6)$. Handles of the manipulator (10) coupled with the internal and external aluminum tube

plant volume. In this way, samples can be safely stored in the field in a cooler for several hours, and in a fridge even for several days, with no threat to the condition of the organisms. The humidity inside the container will prevent fauna and plants from drying off. The organisms will have sufficient amount of air. Lack of water and low temperature will make it difficult for predators to move freely and potentially consume their prey. Such a manner of storage of samples has been successfully practiced not only in the cool and moderate climate zones, but also in considerably warmer, e.g., Mediterranean (Sahuquillo et al. 2008) and tropical climate (Kornijów et al. 2001). Should it be impossible to store samples at a low temperature, e.g., in a cool box, in hot weather, it is safer to preserve the samples immediately after their collection, e.g., by means of $4 \%$ formalin solution. Samples should not
Table 1 Mean densities (number of individuals per $100 \mathrm{~g}$ of plant wet weight $\left.{ }^{-1}\right) \pm \mathrm{SD}(n=6)$ of the most abundant animal taxa associated with $P$. perfoliatus estimated by means of three samplers: $D$-Downing's (1986) sampler, $K_{1}-$ Kornijów's (1998) sampler, and $K_{2}$ - the new sampler

\begin{tabular}{lrrr}
\hline Taxa & \multicolumn{1}{c}{$D$} & \multicolumn{1}{c}{$K_{1}$} & \multicolumn{1}{c}{$K_{2}$} \\
\hline Palaemon sp. & $59 \pm 37$ & $73 \pm 55$ & $65 \pm 26$ \\
Gammarus sp. & $131 \pm 54$ & $155 \pm 44$ & $147 \pm 72$ \\
Chironomidae & $53 \pm 27$ & $65 \pm 31$ & $52 \pm 22$ \\
Total & $243 \pm 96$ & $293 \pm 86$ & $264 \pm 68$ \\
\hline
\end{tabular}

Means not significantly different at $p<0.05$ (the KruskalWallis nonparametric ANOVA tests, StatSoft STATISTICA 10 software)

be frozen. Freezing may cause disintegration of delicate oligochaetes worms Naididae.

Material collected by the sampler permits the estimation of faunal density per plant mass unit (after prior weighing) or per plant surface unit (methods of measurement in: Morse et al. 1985; Watala and Watala 1994; Sher-Kaul et al. 1995). The estimation of the density of fauna in relation to the bottom surface requires a separate estimation of the biomass of plants at the study site by means of larger conventional grab samplers, and the application of the regression analysis for estimating the faunal abundance (Downing 1986).

\section{Preliminary assessment of sampler efficiency}

The efficiency of the new sampler was preliminarily compared with that of two others, constructed by Kornijów (1998), Downing (1986). The study was carried out on June 15, 2014, in the Vistula Lagoon, Southern Baltic $\left(54^{\circ} 20^{\prime} 01 \mathrm{~N}, 19^{\circ} 32^{\prime} 53 \mathrm{E}\right)$, at a depth of $0.5 \mathrm{~m}$, in Potamogeton perfoliatus beds. Six samples, each consisting of about 20-30 g wet weight, were collected with each sampler. The mean densities of the most abundant epiphytic taxa obtained with the application of the three samplers were comparable. Differences between the means were statistically insignificant. This suggests that the applied samplers provide similar results (Table 1).

The presented sampler has the advantage of permitting collecting samples from greater depths. Moreover, it allows for collecting epifauna samples from fragments of single stems of plants located at 
various depths, for the analysis of vertical distribution of invertebrates on plants. It also enables studying the effect of horizontal distribution of invertebrates within a plant patch (e.g., interior and edge).

Acknowledgments The research was conducted as a statutory activity of the Department of Fishery Oceanography and Marine Ecology of the NMFRI, Project Number P1-3. My thanks are due to Małgorzata Kornijów for the English corrections to the paper, to Dr. Leszek Błędzki (Mount Holyoke College, USA) for valuable comments on the first draft of the manuscript and to Dr. Dietmar Straile for inviting me to the Limnological Institute, University of Konstanz, where the prototype of the sampler was produced. The device, as described above, was registered in the Patent Office of Poland, Patent No. A1 383293.

Open Access This article is distributed under the terms of the Creative Commons Attribution License which permits any use, distribution, and reproduction in any medium, provided the original author(s) and the source are credited.

\section{References}

Amoros C (1980) A simple device for quantitative pseudoperiphyton sampling. Hydrobiologia 68:243-246

Brönmark C (1994) Effects of tench and perch on interactions in a freshwater, benthic food chain. Ecology 75:1818-1828

Cheal F, Davis JA, Growns JE, Bradley JS, Whittles FH (1993) The influence of sampling method on the classification ofwetlands macroinvertebrate communities. Hydrobiologia 257:47-56

Colon-Gaud JC, Kelso WE (2003) A suitcase trap for sampling macroinvertebrates in dense submerged aquatic vegetation. J Kans Entomol Soc 76:667-671

Czernik M, Rybak JI (1995) A new sampler for quantitative collection of invertebrate fauna associated with aggregations of filamentous algae and submerged macrophytes. Wiad Ekol 41:89-95 (in Polish, with English summary)

Diehl S, Kornijów R (1998) The influence of macrophytes on trophic interactions among fish and macroinvertebrates. In: Jeppesen E, Sondergaard M, Sondergaard M, Christoffersen M. (eds) The structuring role of submerged macrophytes in lakes. Ecol Stud 131:24-46

Downing JA (1984) Sampling the benthos of standing waters. In: Downing JA, Rigler M (eds) A manual on methods for the assessment of secondary productivity in fresh waters. Blackwell Scientific Publications, Oxford, pp 112-130

Downing JA (1986) A regression technique for the estimation of epiphytic invertebrate populations. Freshw Biol 16:161-173

Galanti G (1995) A volumetric underwater mower (VUM) for hydrophytes assessment. Comparison with alternative methods. Mem Ist Ital Idrobiol 53:115-124

Garcia-Criado F, Trigal C (2005) Comparison of several techniques for sampling macroinvertebrates in different habitats of a North Iberian pond. Hydrobiologia 545:103-115
Gerking SD (1957) A method of sampling the littoral macrofauna and its application. Ecology 38:219-226

Gillespie DM, Brown CJD (1966) A quantitative sampler for macroinvertebrates associated with aquatic macrophytes. Limnol Oceanogr 11:404-406

Gross EM, Kornijów R (2002) Investigation on competitors and predators of herbivorous aquatic Lepidoptera larvae (Acentria ephemerella) on submersed macrophytes. Verhandl Intern Verein Limnol 28:721-725

James MR, Hawes I, Weatherhead M, Stanger C, Gibbs M (2000) Carbon flow in the littoral food web of an oligotrophic lake. Hydrobiologia 441:93-106

Jones IJ, Waldron S (2003) Combined stable isotope and gut contents analysis of food webs in plant-dominated, shallow lakes. Freshw Biol 48:1396-1407

Jones JI, Moss B, Young JO (1998) Interactions between periphyton, nonmolluscan invertebrates, and fish in standing freshwaters. In: Jeppesen E, Sondergaard M, Sondergaard M, Christoffersen M. (eds), The structuring role of submerged macrophytes in lakes. Ecol Stud 131:69-90

Jones JI, Young JO, Eaton JW, Moss B (2002) The influence of nutrient loading, dissolved inorganic carbon and higher trophic levels on the interaction between submerged plants and periphyton. J Ecol 90:12-24

Kairesalo T, Gunnarsson K, Jonasson G, Jonasson PM (1987) The occurrence and photosynthetic activity of epiphytes on the tips of Nitella opaca Ag. (Charophyceae). Aquat Bot 28:333-340

Kangas P (1972) Quantitative sampling equipment for the littoral benthos. II. IBP i Norden 10:9-16

Korinkova J (1971) Sampling and distribution of animals in submerged vegetation. Věst Českosl Spol Zool 35:209-221

Kornijów R (1996) Cumulative consumption of the lake macrophyte Elodea by abundant generalist invertebrate herbivores. Hydrobiologia 319:185-190

Kornijów R (1998) Quantitative sampler for collecting invertebrates associated with submerged and floating-leaved macrophytes. Aquat Ecol 32:241-244

Kornijów R, Kairesalo T (1994) A simple apparatus for sampling epiphytic communities associated with emergent macrophytes. Hydrobiologia 294:141-143

Kornijów R, Szczerbowski JA, Krzywosz T, Bartel R (2001) Epiphytic fauna associated with elodeids of the Iraqi lakes Tharthar and Habbaniya. Arch Pol Fish 9(Suppl.1):125-143

Kornijów R, Vakkilainen K, Horppila J, Luokkanen E, Kairesalo $\mathrm{T}$ (2005) Impacts of a submerged plant (Elodea canadensis) on interactions between roach (Rutilus rutilus) and its invertebrate prey communities in a lake littoral zone. Freshw Biol 50:262-276

Macan TT (1949) Survey of a moorland fishpond. J Anim Ecol 18:160-185

Macan TT (1977) The fauna in the vegetation of a moorland fishpond as revealed by different methods of collecting. Hydrobiologia 55:3-15

Marklund O (2000) A new sampler for collecting invertebrates in submerged vegetation. Hydrobiologia 432:229-231

Martin RG, Shireman JV (1976) A quantitative sampling method for hydrilla-inhabiting macroinvertebrates. J Aquat Plant Manage 14:16-19 
Matuszak A, Mörtl M, Quillfeldt P, Bauer HG (2014) Macrophyte-associated macroinvertebrates as an important food source for wintering waterbirds at Lake Constance. Limnology 15:68-76

McCauley VJE (1975) Two new quantitative samplers for aquatic phytomacrofauna. Hydrobiologia 461:81-89

Minto ML (1977) A sampling device for invertebrate fauna of aquatic vegetation. Freshw Biol 7:425-430

Morse DR, Lawton JH, Dodson MM, Williamson MH (1985) Fractal dimension of vegetation and the distribution of arthropod body lengths. Nature 314:731-732

Moss BR (2010) Ecology of Fresh Waters: A View for the Twenty-First Century, 4th edn. Wiley-Blackwell Science LTD, Oxford

Newman RM (1991) Herbivory and detritivory on freshwater macrophytes by invertebrates: a review. J North Am Benthol Soc 10:89-114

Perrow MR, Jowitt AJD, Stansfield JH, Phillips GL (1999) The practical importance of the interactions between fish, zooplankton and macrophytes in shallow lake restoration. Hydrobiologia 395(396):199-210

Sahuquillo M, Miracle MR, Rieradevall M, Kornijów R (2008) Macroinvertebrates assemblages on reed beds, with special attention to Chironomidae (Diptera), in Mediterranean shallow lakes. Limnetica 27:239-250

Sher-Kaul S, Oertli B, Castella E, Lachavanne JB (1995) Relationship between biomass and surface area of six submerged aquatic plant species. Aquat Bot 51:147-154

Sychra J, Adámek Z (2010) Sampling efficiency of Gerking sampler and sweep net in pond emergent littoral macrophyte beds-a pilot study. Turk J Fish Aquat Sci 10: 161-167

Watala KB, Watala C (1994) A photometric technique for the measurement of plant surface area: the adsorption of plant surface area: the adsorption of Brilliant Blue dye on to plant surface. Freshw Biol 31:175-181 